
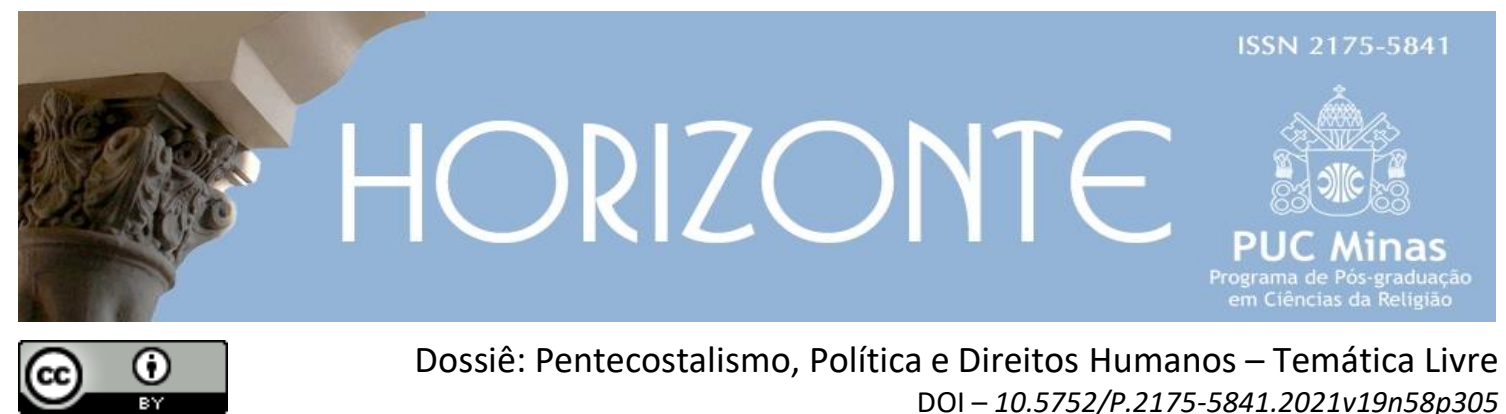

Dossiê: Pentecostalismo, Política e Direitos Humanos - Temática Livre

DOI - 10.5752/P.2175-5841.2021v19n58p305

\title{
“Sem religião" ou pluralismo religioso? Uma leitura introdutória
}

\author{
"Without religion" or religious pluralism? \\ An introductory Reading
}

José Reinaldo Felipe Martins Filho*

Clóvis Ecco**

\begin{abstract}
Resumo
Este artigo se insere na perspectiva das atuais discussões sobre os "sem religião", uma categoria que tem despertado interesse de cientistas da religião, teólogos e estudiosos em geral sobretudo para os que discutem as novas tendências das sociedades secularizadas, a relação entre religião e cultura e o individualismo. Esta é a primeira parte de um trabalho que se subdivide em três partes. Como alude o título, trata-se de uma leitura introdutória ao tema, com base nos dados do Censo de 2010 e em duas outras pesquisas por nós desenvolvidas entre 2015 e 2017. Sua metodologia de análise toma como pressuposto os dados obtidos pela pesquisa quantitativa, questionando-os, em seguida, à luz de uma interpretação mais profunda, que ultrapasse a mera leitura dos índices percentuais graças ao que foi obtido nas respostas qualitativas. Como resultados, questionamos a validade do conceito "sem religião" como tem sido comumente empregado, levantando pistas para a leitura do pluralismo religioso que lhe é subjacente. $\mathrm{O}$ artigo se completará com suas outras duas partes, que virão a público oportunamente.
\end{abstract}

Palavras-chave: Sem religião. Pluralismo religioso. Secularização. Individualismo.

\begin{abstract}
This article is part of the current discussion of "without religion", a category that has attracted interest from religion scientists, theologians and scholars in general - especially for those who discuss the new trends of secularized societies, the relationship between religion and culture and individualism. This is the first part of a work that is subdivided into three parts. As the title alludes to, this is an introductory reading to the topic, based on data from the 2010 Census and two other surveys we developed between 2015 and 2017. Its analysis methodology takes as presupposition the data obtained by the quantitative research, then questioning them in the light of a deeper interpretation, which goes beyond the mere reading of the percentage indices thanks to what has been obtained in the qualitative answers. As results, we question the validity of the concept "without religion" as it has been commonly used, raising clues for the reading of the religious pluralism that underlies it. The article will be completed with its other two parts, which will come to the public in due course.
\end{abstract}

Keywords: Without religion. Religious pluralism. Secularization. Individualism.

Artigo submetido em 6 de julho de 2019 e aprovado em 25 de maio de 2021.

\footnotetext{
* Doutor em Ciências da Religião pela PUC Goiás. Professor no Instituto de Filosofia e Teologia de Goiás. País de origem: Brasil. E-mail: jreinaldomartins@gmail.com

**Doutor em Ciências da Religião pela PUC Goiás. Prof. da PUC Goiás. País de origem: Brasil. E-mail: clovisecco@uol.com.br
} 


\section{Introdução}

Entre os principais temas que atualmente ocupam a reflexão de teólogos, cientistas da religião e demais pesquisadores de áreas afins, certamente está a questão dos "sem religião" (MARTINS FILHO; ECCO, 2018, p. 33). Noutras palavras, trata-se de um dos grandes filões da pesquisa contemporânea acerca do fenômeno religioso e suas implicações para as novas composições sociais. Aliás, não somente no que respeita ao papel da religião para a sociedade de maneira geral, mas também a considerando em sua função de compor identidades, ressignificando e refratando valores. A delimitação do fenômeno religioso, então, tanto pode nos auxiliar na compreensão dos homens e das mulheres de hoje - como reflexo de sua constituição identitária - quanto, percorrendo o caminho inverso, mensurar o alcance e a plausibilidade conferida aos discursos religiosos pelo meio de vida corrente. Fenômenos como esse mostram-se, então, como oportunidades privilegiadas de aprofundarmos a reflexão, individual e coletiva, extrairmos chaves de leitura e interpretação e fomentarmos uma discussão que alcance o fulcro das relações concretas (COSTA; ECCO; MARTINS FILHO, 2017, p. 9-10).

Particularmente, o tema dos "sem religião" chegou a nós pela via indireta, como fruto paralelo de uma pesquisa dirigida pelo professor Dr. Clóvis Ecco a respeito do ateísmo contemporâneo. Por sinal, aquele também foi o momento a partir do qual estabelecemos nossa parceria, quantificando, analisando e interpretando os dados oriundos do campo de estudos. Para nossa surpresa, entre os resultados que mais chamaram a nossa atenção foi o significativo percentual dos que se autointitularam “sem religião”. Embora não se trate de uma questão propriamente nova, permanece revestida de uma atualidade patente.

Embora sua aparição nas discussões acadêmicas já tivesse sido objeto de interesse de vários pesquisadores, como Alberto Antoniazzi (2003), Antônio Flávio Pierucci (2004) e Regina Novais (2004), a publicação dos resultados do censo de 2010, realizado pelo Instituto Brasileiro de Geografia e Estatística (IBGE), reacendeu o debate, potencializando o seu alcance a respeito do tema. 
Para a inquietação de muitos, ao contrário do que havia se consolidado como o padrão das décadas anteriores, o crescimento dos evangélicos, com proporcional redução no número estimativo de católicos no país, apresentava estagnação pela primeira vez em décadas - note-se, entre outros, o primoroso trabalho organizado por Faustino Teixeira e Renata Menezes (2013). Mesmo que o chamado "grande cristianismo" continuasse a ocupar posição preponderante com relação às demais religiosidades, agnósticos e ateus também exibiram sinais de expansão. Como foco de maior interesse, porém, destacavase uma categoria que, embora despontada já desde o censo de 2000, a partir de 2010 despertara particular interesse dos pesquisadores e estudiosos do fenômeno religioso: os "sem religião".

Desde então, muito tem sido discutido sobre o assunto, dividindo a opinião de especialistas, líderes religiosos e do público em geral. A par disso, porém, com base nas últimas pesquisas por nós realizadas, a categoria conceitual acionada de forma recorrente a partir do censo de 2010, como demonstraremos, não corresponde ao real formado do perfil religioso dos brasileiros (MARTINS FILHO, 2020, p. 94). Isso porque parece não se tratar simplesmente de indivíduos descomprometidos com a dimensão religiosa em suas vidas, mas "autônomos" na construção do formato de religião que professam. Dizemos isso com base na palavra de muitos entrevistados, os quais não se confessaram apenas como "sem religião", mas como "crentes, sem religião”, o que inaugura um horizonte completamente distinto a partir do qual devemos empreender nossa análise. Este é, portanto, o ponto de ensejo da discussão explicitada nas páginas que seguem, as quais buscam delimitar algumas balizas a fim de pensarmos quem são os "sem religião" no Brasil de hoje, nomeadamente, a partir do resultado de algumas de nossas pesquisas, problematizando a leitura geralmente praticada pelo senso comum no exercício de compreensão desse fenômeno.

\section{Pressupostos de pesquisa e perspectivas de análise}

Ao longo das últimas décadas, a cada novo censo realizado pelo Instituto Brasileiro de Geografia e Estatística (IBGE), cria-se alguma expectativa com 
respeito ao cenário religioso, pelos líderes religiosos, pelos estudiosos do fenômeno religioso e pelo público em geral. A grande mídia geralmente tem concentrado seus esforços em anunciar a progressiva diminuição dos católicos e o crescimento do chamado neopentecostalismo, termo que compreende um conjunto de denominações religiosas cristãs surgidas no princípio do século XX. O censo de 2010, contudo, ampliou significativamente as interpretações até então praticadas. Não apenas enfatizou o surgimento de novas religiosidades e manifestações do "crer" e do "não crer" no panorama brasileiro, mas o significativo percentual aferido para os chamados "sem religião".

Em primeiro lugar, não podemos confundi-los com os autodeclarados ateus ou agnósticos, categorias para as quais o censo também manifestou um percentual indicativo. Nesse sentido, a fim de melhor compreendermos o que está incluído na categoria "sem religião" apontada pelo censo de 2010 é necessário levarmos em conta o que afirma o Manual do Recenseador (2010), particularmente no que tange aos objetivos do censo em se tratando da mensurabilidade da experiência religiosa brasileira. Sobre o objetivo da questão 6.12, referente à religião professada pelo entrevistado, o referido manual sentenciava: "a finalidade deste tema é conhecer quais as religiões declaradas pela população e o número de seus adeptos” (IBGE, 2010, p. 195). Há, inclusive, uma exceção oferecida aos indivíduos pertencentes às etnias indígenas, para os quais também foram consideradas como religião as "crenças tradicionais e práticas rituais próprias do seu povo” (IBGE, 2010, p. 195).

Em geral, os entrevistados foram submetidos à seguinte questão: qual é a sua religião ou culto? Ao que deveriam interpor mencionando a instituiçãoigreja, seita, culto ou ramo da religião por ele próprio professada, tais como, a título de exemplificação, o próprio Manual oferecia as seguintes opções:

Católica Apostólica Romana, Católica Apostólica Brasileira, Luterana Pentecostal, Batista, Assembleia de Deus, Universal do Reino de Deus, Congregação Cristã do Brasil, Adventista do Sétimo Dia, Kardecista, Xintoísmo, Testemunhas de Jeová, Candomblé, Umbanda, Budismo, Israelita, Maometana (ou Islamita), Esotérica. (IBGE, 2010, p. 195). 
Ainda em concordância com a orientação, não deveriam ser registradas expressões genéricas como Católica, Protestante, Espírita, sem a especificação de suas relativas subcategorias, como apontado acima. Também não se permitia ao recenseador induzir a resposta do entrevistado, nem, tampouco, deduzir a partir das declarações do informante, sendo única e estritamente permitido o registro da informação oferecida por este. Em caso de crianças e jovens menores de idade, poder-se-ia, porém, registrar a religião da mãe. Este ponto voltará adiante, quando nos dedicaremos a levantar algumas hipóteses que justifiquem a consolidação do atual pluralismo religioso, entre as quais merecerá destaque a reconfiguração familiar, o crescente protagonismo dos jovens em questão de escolha religiosa, além, notadamente, dos processos de emancipação feminina observados na geração atual em comparação com a última geração. Vale, inclusive, questionar o alcance do pretendido "pluralismo", vez que, conforme pudemos observar em outra oportunidade (MARTINS FILHO, 2019, p. 664), o uso desse termo pode escamotear a manutenção do paradigma cristão através de formas desinstitucionalizadas, o que, necessariamente, não implicaria num "pluralismo religioso" de fato. Por último, constava aos recenseadores a orientação que vai ao encontro de nosso tema específico: "para a pessoa que não professa qualquer religião, registre sem religião” (IBGE, 2010, p. 196).

Para início de conversa, esta informação se apresenta fortemente relevante. Isso porque, embora estejamos apresentando a questão específica dos “sem religião" como emergente a partir do censo de 2010, devemos admitir que, nos termos estritos da orientação oferecida aos recenseadores, seriam incluídas nesta categoria apenas as pessoas para quem a religião não ocupasse nenhuma função significativa, ou melhor, aqueles que não apenas não mantêm quaisquer vínculos institucionais, mas também não se reconhecem diante do papel da religião em suas vidas, seja numa perspectiva comunitária, seja pela ótica individual.

Tal observação, por sua vez, nos conduz a, pelo menos, três constatações: 
a) pela nomenclatura "sem religião" estaríamos lidando com pessoas indiferentes à dimensão religiosa, haja vista não optarem nem por se incluírem na categoria de "ateus" ou "agnósticos", nem por manifestarem quaisquer outras formas de crença alusivas ao termo "religião" - aqui se encontrariam aqueles que exercem seu potencial simbólico de outras formas que não estritamente ligados a uma configuração religiosa, seja por escolha pessoal, seja por origem familiar;

b) na categoria "sem religião" poderiam estar incluídos os indivíduos que no momento de responderem o questionário não souberam precisar sua subscrição a nenhuma denominação/instituição específica, como é o caso dos chamados "desigrejados", tendo como consequência a sua vinculação junto ao grupo dos "sem religião" - esta parcela seria resultante do "trânsito religioso", dos processos de bricolagem ou outros fenômenos que dificultam uma mensurabilidade específica, ainda que, em nenhuma hipótese, signifique serem "descrentes" da dimensão religiosa como tal;

c) enfim, junto aos "sem religião" também se encontrariam sujeitos altamente religiosos, isto é, para os quais a dimensão das crenças permanece ocupando um espaço fundamental em sua configuração de sentido, mas que, por motivos diversos, afastaram-se das instituições religiosas, passando a desenvolver uma "espiritualidade" de caráter pessoal - seriam os chamados “crentes sem religião”, aos quais nos dirigiremos mais especificamente adiante (conceito que tivemos a oportunidade de dialogar com o catalão Marià Corbi). (MARTINS FILHO; ECCO, 2017).

Conforme os dados do censo de 2010, os ateus e os "sem religião", que em 1960 eram 0,6\% da população no Brasil, representam atualmente 8\% percentual significativamente maior entre os mais jovens. Ao todo 15 milhões de pessoas responderam não possuir religião, dos quais 615 mil afirmaram 
expressamente serem ateus e 124 mil agnósticos. É possível identificar um aumento de $130 \%$ com relação aos últimos 50 anos entre as pessoas que deixaram de acreditar em uma divindade ou em quaisquer forças sobrenaturais.

Houve também um encolhimento das pessoas que, na pesquisa anterior, diziam-se católicas. Apesar de o grupo dos evangélicos (pentecostalismo tradicional) também ter sofrido algum aumento, o crescimento considerável dos ateus e "sem religião" é o que realmente chamou a atenção numa comparação entre 1960 e 2010. Nalguns Estados da Federação o resultado ainda foi mais significativo, como é o caso do Estado de Goiás, em que o percentual de pessoas incluídas na categoria "sem religião" atingiu os 9\%, ficando, portanto, 1\% acima da média nacional.

Consoante ao que acabamos de dizer sobre o atual contexto das religiões no Brasil em números inteiros e percentuais, respectivamente, também gostaríamos de levar em conta alguns dos dados obtidos por duas pesquisas por nós realizadas junto aos jovens universitários. A primeira (aqui nomeada P1), empreendida na passagem de 2016 para 2017, considerou um total de 80 estudantes (cf. ECCO; MARTINS FILHO, 2017)ํ, consultados a respeito de suas crenças e/ou descrenças. A segunda (doravante representada como P2), relativa aos anos de 2015 a 2017, contou com uma população expressivamente maior, com participação média de $900^{2}$ entrevistados com base num formulário que incluía tanto questões de múltipla escolha, com opções previamente estabelecidas, como de resposta aberta, com possibilidade de discussão dos sujeitos em torno da temática explorada (cf. LEMOS; SOUSA; MARTINS FILHO, 2018).

\footnotetext{
${ }^{1}$ Aqui nos referimos à pesquisa dirigida pelo professor Dr. Clóvis Ecco junto aos estudantes das disciplinas da área de teologia da Pontifícia Universidade Católica de Goiás, com o título Culturas e ateísmos contemporâneos, com autorização do Comitê de Ética em Pesquisa sob o número CAAE 48968115.4.00oo.o037. Resultados mais acabados foram publicados no volume 10, número 2, da Revista Mosaico, da PUC Goiás, disponível ao acesso virtual.

${ }^{2}$ Temos em conta a pesquisa coordenada pela professora Dra. Carolina Teles Lemos junto aos estudantes do primeiro período de todos os cursos de graduação da Pontifícia Universidade Católica de Goiás, com o título Juventude e religiosidade: o caso de jovens universitários, também devidamente aprovada pelo Comitê de Ética em Pesquisa sob número CAAE 38480614.1.00oo.0037. A pesquisa completa, discutida a partir dos diferentes enfoques explorados pela coleta de dados, foi publicada pela Fonte Editorial no início de 2018, num livro que leva o mesmo título. Por esta ocasião, tivemos o prazer de trabalharmos na organização do material inédito em função da publicação, pelo que agradecemos publicamente o convite da professora Carolina Lemos.
} 


\section{Concepções da crença e da descrença na contemporaneidade}

Com ênfase à primeira pesquisa (P1), considerando o número total dos participantes, a margem dos que afirmaram praticar alguma atividade religiosa constituiu praticamente o dobro daqueles que disseram não fazê-lo. Em vista disso, entre as principais atividades desenvolvidas pelo grupo dos religiosos foram apontadas: ler a Bíblia, ir à missa ou ao culto e outros tipos de orações de origem cristã, embora praticadas individualmente. Também pudemos verificar significativas respostas no tocante à imagem de Deus/divindade que estes estudantes demonstraram possuir. À semelhança do que também ocorre nas religiões monoteístas, mantém-se a ideia de uma divindade masculina, no mais das vezes identificada à figura paterna, donde provém toda proteção e estabilidade - e aqui seria impossível não recordarmos as funções atribuídas por Clifford Geertz (2001) à religião, como segue: uma experiência que confere sentido, pertencimento e poder. Raros depoimentos fizeram exceção a essa regra, sendo representativas concepções de Deus como mãe, energia, força e família.

Figura 1 - Dados percentuais da atividade religiosa (cf. P1).

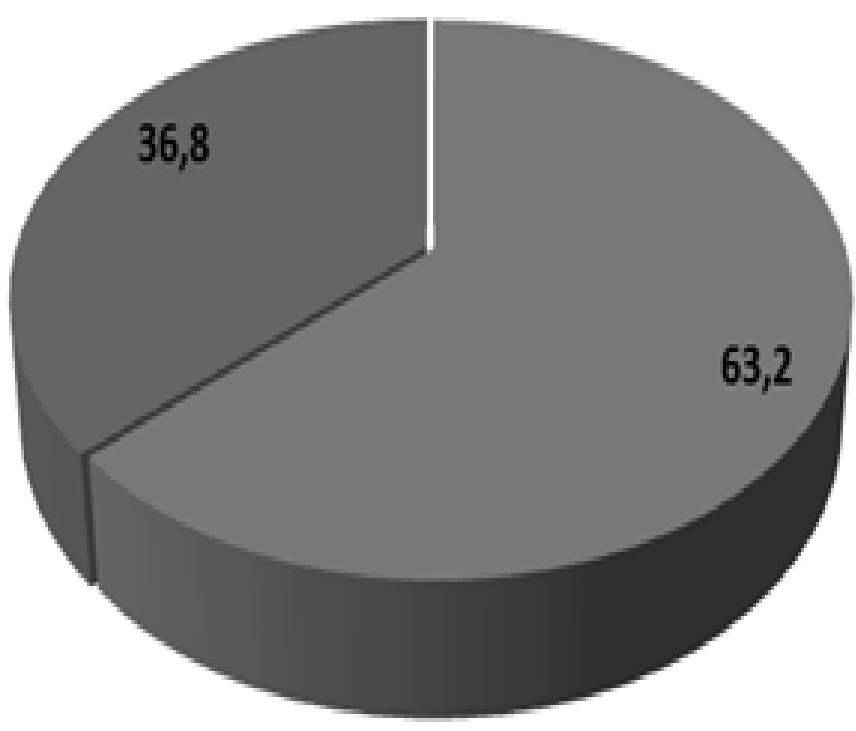

Fonte: Elaborado pelos autores. 
Por conseguinte, entre os dados mais expressivos para nossa discussão observamos o acentuado aumento na variedade de religiões evocadas pelos jovens participantes em comparação com a prática religiosa de seus genitores. Enquanto o número comum de religiões dos pais e mães não passou de 9 e 6 denominações, respectivamente, no caso dos filhos chegamos a um total de 13 distintas manifestações institucionais. Além disso, caso comparemos o número de religiões dos filhos ao de suas mães, por exemplo, trata-se de um aumento de mais de $100 \%$.

Com o advento do pluralismo religioso, contudo, também constatamos o crescimento daqueles que se reconheceram ateus ou "sem religião". O percentual dos que afirmaram crer, embora não possuir vinculação a nenhuma instituição específica, correspondeu ao terceiro maior número percentual do grupo estudado - sendo praticamente equivalente a adesão por parte de ambos os sexos, masculino e feminino. Além disso, caso tomemos em comparação o gráfico de crença dos pais e mães dos estudantes consultados, logo percebemos a inexistência de "descrentes" e/ou “ateias" no grupo das mães - isso na contramão do que se imiscui dos relatos da geração à qual pertencem as estudantes que integraram a pesquisa, com relevante número de autodenominadas ateias ou "sem religião".

Relativamente à religião das mães, vale a pena lembrar que apenas tivemos por base a afirmação fornecida pelos filhos. Pesquisas semelhantes sobre o percentual religioso de mulheres chegaram a números bastante diferentes. Entre outros motivos, provavelmente isso tenha ocorrido pelo fato de a consulta ter sido realizada junto às próprias mulheres entrevistadas. Em contrapartida, ao serem perguntadas se, acaso, manifestariam a mesma resposta oferecida à pesquisa aos seus próprios filhos, a grande maioria das denominadas "sem religião" ou ateias responderam: não. Assim, é bem possível que os números obtidos por nossa pesquisa para o espectro geral das religiões praticadas pelas mães devam ser relativizados, aspecto que de forma alguma diminui a validade do experimento como um todo no que compete à discussão sobre os "sem religião", já que também não podemos deixar de considerar o 
crescente espaço granjeado para o exercício das liberdades individuais na sociedade atual.

De outro lado, embora já goze amplamente dos influxos da modernização, que trouxe consigo os processos de secularização e pluralismo religioso como inerentes à composição social, alguns preconceitos de caráter religioso ainda persistem no Brasil de hoje, levando pessoas a se sentirem coagidas a manifestarem-se em conformidade ao que realmente praticam no âmbito de suas crenças. Este dado, aliás, pode conduzir-nos a um percentual acentuadamente maior que o aferido por ambas as pesquisas - a do censo de 2010 e a que nós mesmos realizamos junto aos jovens universitários - o que, incontornavelmente, nos obrigaria a levar em conta a distinção entre "crentes praticantes" e os autointitulados crentes, inclusive com menção de pertencimento institucional, mas que, no âmbito de suas vidas concretas, não demostram laços efetivos de adesão seja à doutrina, seja à prática do referido credo.

Por fim, com respeito à crença e à descrença generalizadas, tanto o resultado do Censo de 2010, quanto nossa pesquisa de campo (P1) indicam não apenas o crescimento no número dos ateus, mas o surgimento desta nova categoria de análise para as ciências da religião e a teologia, como segue: os crentes “sem religião". Quiçá tal indicação possa ser tomada como um indício de que os processos de secularização, como uma das principais características da contemporaneidade, não terão no Brasil os mesmos contornos esboçados em outros cantos do mundo. Ao contrário, a crença religiosa parece subsistir como um importante instrumento de manutenção de sentido não apenas em nível individual, mas social.

No que compete aos "sem religião", então, por ora admitimos tratar-se não de um fenômeno a-religioso e/ou resultante de um arraigado processo de descrença que, pouco a pouco, generalizou-se, mas de novas formas ensaiadas pelos indivíduos em busca da manutenção de sua dimensão simbólica, do substrato vital representado pela expressão religiosa. Em vista disso, as antigas ordens e hegemonias, validadas pelo modelo institucional, parecem lograr cada vez menos espaço. 


\section{3 “Sem religião" ou pluralismo religioso?}

Partindo do que dissemos até aqui, chegamos ao momento de retomarmos a segunda pesquisa por nós realizada (no intervalo de 2015 e 2016), também referente ao universo das crenças professadas pelos estudantes universitários, embora agora com um alcance populacional significativamente maior (P2). Tal esforço possibilitará demonstrar sua articulação (no sentido de sustentação comprobatória) e reação (recusando alguns dos elementos expostos) à concepção geralmente praticada ao redor do conceito "sem religião" em sentido genérico, como o equivalente à “descrença”.

Ao longo do processo de pesquisa (P2) os estudantes dos cursos de graduação foram distribuídos por área de concentração, conforme estabelecem as diretrizes educacionais do Ensino Superior no Brasil. Apesar de os questionários também terem explorado temas como os principais rituais religiosos adotados pelos estudantes, bem como a sua frequência na vida dos mesmos, ou, igualmente, os tipos de oferta religiosa expostos pelas tecnologias midiáticas e o trânsito religioso dos jovens por diferentes segmentos de crença (ou não crença), nossa análise aqui também privilegiará - como fizemos anteriormente - a resposta oferecida para a questão que toca a profissão religiosa manifestada pelos próprios discentes, e, conseguintemente, por seus pais e suas mães.

Tal opção se justifica, de um lado, por estas questões expressarem o resultado quantitativo, em sentido estrito, do perfil religioso dos jovens universitários pesquisados - já em comparação com a opção religiosa de seu núcleo familiar - e, de outro, porque nos permitirá desenvolver o argumento de que as teses expostas pelas ciências humanas e sociais acerca do fenômeno religioso nas últimas décadas, particularmente no que tange às suas previsões sobre o "futuro da religião", apenas parcialmente mantiveram sua validade sobretudo considerando o amplo horizonte representado pelo contexto da realidade latinoamericana e, mais especificamente, brasileira. De maneira geral, é possível diagnosticar que apesar de significativa dispersão em suas crenças e, em alguns casos, de suas "descrenças", os estudantes entrevistados ainda professam sua inserção e integração a algum tipo de religião (ou de "novas 
religiosidades", à luz do que dissemos anteriormente e concordando com os mais diferentes experimentos realizados na tentativa de aferir a melhor forma de tratamento à realidade estudada).

Em primeiro lugar, vejamos a tabela pertinente ao quadro de crenças e opções religiosas dos próprios estudantes:

Tabela 1 - Pluralismo religioso dos participantes (cf. P2).

\begin{tabular}{|l|r|r|}
\cline { 2 - 3 } \multicolumn{1}{l|}{} & \multicolumn{1}{c|}{ Qtd } & \multicolumn{1}{c|}{$\%$} \\
\hline $\begin{array}{l}\text { Evangélico } \\
\text { Pentecostal }\end{array}$ & 161 & 17,6 \\
\hline $\begin{array}{l}\text { Evangélico } \\
\text { Tradicional }\end{array}$ & 74 & 8,1 \\
\hline Afro Brasileira & 2 & 0,2 \\
\hline Oriental & 50 & 5,5 \\
\hline Espírita & 323 & 35,2 \\
\hline Católica Romana & 27 & $\mathbf{2 , 9}$ \\
\hline Religião Particular & 163 & $\mathbf{1 7 , 8}$ \\
\hline Crente “sem religião" & 33 & 3,6 \\
\hline Ateu & 34 & 3,7 \\
\hline Agnóstico & $\mathbf{3 6}$ & $\mathbf{3 , 9}$ \\
\hline Outra acumulada3 & & \\
\hline
\end{tabular}

Fonte: Elaborada pelos autores.

Da massa arbitrária de $100 \%$ do recorte populacional entrevistado, a Igreja Católica Apostólica Romana figurou como principal opção religiosa dos jovens universitários, num percentual de 35,5\%. Contudo, em termos do chamado "grande cristianismo" este número aumentaria para 66.8\%, inclusos os 8.1\% dos evangélicos tradicionais, mais 17,7\% dos evangélicos pentecostais e, ainda, os $5.5 \%$ da confissão espírita, que também encontra suas bases na

\footnotetext{
3 Este grupo diz respeito a denominações das mais diferentes origens e famílias religiosas, sendo que, de maneira geral, poderiam ser abarcadas por duas categorias: a) as formações híbridas a partir das denominações oferecidas pelas opções anteriores, tais como "católica-espírita", "pentecostal-exotérica", etc.; b) e de religiões exotéricas com percentual bastante pequeno em comparação com as demais mencionadas, tais como "tarô", "xamanismo", "santo daime", etc., nenhuma das quais com número percentual superior a $0,1 \%$ do total da pesquisa - conforme normas técnicas para investigações dessa natureza.
} 
doutrina cristã - apesar de, notadamente, também divergir desta4. Tudo isso, por outro lado, contrasta com o resultado total de 27,2\%, para o qual os jovens universitários se consideram ateus (3,6\%), agnósticos (3,7\%), possuindo uma religião particular (3,0\%), ou, com percentual curiosamente significativo, autointitulados crentes "sem religião" (17,9\%) - um total que, apesar de consoante ao crescimento destes fenômenos no Brasil de maneira geral, superou os números gerais aferidos pelo censo de 2010.

Um primeiro grupo, ao qual chamamos "espiritualistas", constitui minoria quando comparado à religião cristã, estando integrado pelo orientalismo (0,2\%) e pelos movimentos de matriz afro-brasileira (o,8\%). Outras religiões compuseram um percentual de praticamente 4,0\%, - dado que este item concentrou o maior número de incompreensões por parte dos respondentes, já que, em sua maioria, as respostas oferecidas para a categoria "outras religiões" poderiam ser enquadradas em alguma forma do cristianismo - ainda que híbrida.

É verdade que nas últimas décadas o pluralismo religioso consolidou-se no Brasil e o mercado religioso tornou-se altamente competitivo, provocando mudanças consideráveis nos processos de interação entre os próprios grupos religiosos e deles com os agentes e instituições seculares. Fazendo jus a esta constatação, o resultado global de nossa pesquisa (P2) tomou por amostra uma proporção igualmente apurada entre os cursos e suas áreas de concentração de conhecimento. Apesar disso, porém, entre os cursos puderam ser verificadas algumas variações de opção religiosa entre o catolicismo, os evangelicalismos (pentecostal e tradicional) e o espiritismo (embora este, excetuando a doutrina da reencarnação, tenha por base princípios comuns ao cristianismo católico).

Em alguns casos, por exemplo, o percentual de católicos mostrou-se superior ao de evangélicos ou de espíritas, variação que, embora oscilante de um curso para outro, manteve a preponderância religiosa dos jovens em sua filiação a uma destas três denominações. As demais categorias de análise ou indicadores acerca dos critérios de religiosidade não apresentaram expressiva alteração de

\footnotetext{
4 Optamos por inserir o espiritismo brasileiro junto às demais expressões do cristianismo seguindo o princípio da afinidade eletiva, que prima por fundamentos doutrinais semelhantes, bases de crenças comuns, embora também estejamos conscientes de seu distanciamento.
} 
percentual entre si. O ateísmo e o agnosticismo, de um curso para o outro, mantiveram simetria em números percentuais, decorrendo num resultado global, mesmo que novamente tenham se destacado os declarados "sem religião" - a esta altura, contudo, prefixados pela expressão “crentes”, isto é, “crentes sem religião”.

No tocante à resposta oferecida pelos estudantes para a pergunta acerca da religião de seus pais, dado o caráter fechado das opções oferecidas para a questão, notamos o mesmo número de opções dadas à pergunta anterior. Apesar da variedade similiar, contudo, fez-se ainda mais evidente o monopólio do "grande cristianismo" sobre as outras formas de expressão da religiosidade, especialmente em face da tímida manifestação de agnósticos ou ateus entre os pais - isso apesar de estes ainda terem sido mencionados (um total de 17 indivíduos, em números inteiros). Apenas a categoria "crente sem religião" manteve-se com resultado percentual relativamente próximo à opção dos filhos, o que, eventualmente, indicaria o crescimento linear deste fenômeno ao longo das últimas décadas - pondo em xeque já o resultado obtido pelos censos anteriores a 2010.

Sobre da religiosidade de suas mães a resposta dos entrevistados conduziu a um total de pouco mais de 50\% de católicas, estimando que o "grande cristianismo" seria responsável por quase 90\% do percentual total. Apesar disso, a variedade de religiões evocadas superou o elenco oferecido para as religiões tanto dos estudantes, quanto de seus pais. Isso porque houve a inclusão de uma mãe de religião "islâmica", dado inédito em toda a nossa pesquisa. Entre ateísmo, agnosticismo e "crentes sem religião”, o percentual religioso das mães sequer alcançou os 10\% - evidência significativa para o desenvolvimento de alguns pontos da análise que seguirá no próximo movimento.

\section{Uma leitura crítica para concluir}

Olhando a partir dos dados extraídos tanto do censo de 2010, quanto de nossas pesquisas (P1 e P2), podemos aferir que a dimensão religiosa do indivíduo contemporâneo se esboça, no mais das vezes, como uma busca de 
experiências (de transcendência e/ou como integração social, remissão moral, entre outros). A "presença" do sagrado passa a ser tomada como sinônimo de força para a superação de dificuldades, como companhia nos momentos de solidão e desventuras existenciais. Tal pode ser notado, entre outros, no depoimento de duas estudantes, ambas autointituladas "crentes sem religião". Para a primeira, "a sociedade necessita do temor de Deus, necessita sentir a presença dele" (19 anos). Para a segunda, "a sociedade mais religiosa tem seus princípios morais melhores, o respeito às pessoas e a fé na vida e num crescimento saudável e espiritual” (39 anos) (cf. LEMOS; SOUSA; MARTINS FILHO, 2018, p. 219). Em vista das respostas oferecidas, contrastando com a opção religiosa escolhida por ambas, uma primeira pergunta nos viria à mente: que espécie de “crentes sem religião" seriam essas, afeitas a uma imagem e presença de Deus e à influência social da religião?

De fato, em concordância com essas asserções, a experiência religiosa pode ser considerada como um fenômeno marcante na vida de um relevante número de pessoas, sempre levando em conta o seu duplo direcionamento, como segue: reforçando os laços comunitários e sociais e resguardando a esfera individual como espaço igualmente privilegiado para o exercício da crença. Desse modo, religião e religiosidade expressam a cultura contemporânea em sua profundidade, isto é, um emaranhado de significados simbólicos que permite entender o universo das ideias e mentalidades, os ritos do cotidiano, as relações sociais, em suma, permite entender a "alma” do ser humano - e, quiçá, do povo brasileiro - através de um mergulho no cerne de sua identidade.

Clifford Geertz foi um dos primeiros a teorizarem sobre o fundamento cultural da religião, entendendo-a como o "padrão de significados transmitidos historicamente, incorporado em símbolos, um sistema de concepções herdadas expressas em formas simbólicas por meio das quais os homens comunicam, perpetuam e desenvolvem seu conhecimento e suas atividades em relação à vida.” (GEERTZ, 1989, p. 66-67). Tal afirmação implica que os símbolos religiosos estabelecem uma harmonia fundamental entre um estilo de vida particular (ethos) e uma metafísica específica (cosmovisão). 
Por um lado, contribuem na formulação de pilares morais que posteriormente acabam por se consolidar como os parâmetros norteadores da relação entre os indivíduos e o meio de vida social em que se encontram. Por outro, configuram a cosmovisão não apenas dos indivíduos tomados isoladamente, mas de toda uma comunidade ou, mesmo, de uma sociedade, definindo o modo específico das relações, legitimando ou reagindo contra hierarquias e hegemonias, estabelecendo os limites da identidade, do pertencimento. Isso é explicitado no testemunho de um dos estudantes entrevistados, este de 24 anos, também consciente de sua crença, embora insista não pertencer a nenhuma instituição religiosa em particular: "[a crença] é o desenvolvimento da bondade interior, [o que] ajuda a construir uma sociedade melhor, mais humanitária e menos predadora, onde também os mais fracos sobrevivam, e não somente os fortes" (cf. LEMOS; SOUSA; MARTINS FILHO, 2018, p. 220). É, pelo menos, curioso o adjetivo por ele empregado na definição de nossa sociedade: predadora!

É verdade que o aspecto relacional pode ser considerado como um dos pontos nevrálgicos de nossas análises. Ora como reação ao esfacelamento dos vínculos duradouros, ou, talvez, para atestar o surgimento de novas composições, avessas ao modelo mantido ao longo dos últimos séculos. Contudo, também não podemos desprezar que entre os nomeados "sem religião" subsiste uma real busca por transcendência: "é difícil falar o mais importante, mas eu acho que na religiosidade em si, o transcendente é o mais importante" (20 anos, sexo feminino) (cf. LEMOS; SOUSA; MARTINS FILHO, 2018, p. 220).

A fim de mensurar o sentido da expressão "experiência religiosa” e, ao mesmo tempo, tentar traduzi-la em termos compreensíveis a uma linguagem ao menos minimamente aceitável para os parâmetros da razoabilidade, podemos tomar por empréstimo o termo Erlebnis. Essa palavra, originada da filosofia alemã, com acento proeminente nas obras de autores como Hegel (1970) e, sobretudo, Nietzsche (1980), pode ser traduzida por "vivência" e/ou "experiência”. Em geral evoca o sentido de algo que é experimentado desde dentro, desde o mais profundo da existência - recorrendo à metáfora da 
profundidade para expressar a dimensão interior à qual já Agostinho (1984) fazia alusão. O “vivenciado", portanto, resgata o caráter de algo que adquire valor para o indivíduo - e o uso do artigo definido aqui é imprescindível. Na verdade, de um valor autoevidente, também podendo ser entendido como "reconhecimento".

Na experiência religiosa é o próprio indivíduo que se reconhece como ser multidimensional que é, dotado de necessidades simbólicas que são tão "reais" quanto à sua esfera biofisiológica que o expõe ao mundo dos demais. Aqui estão implicadas desde instâncias como a emoção e a criatividade até a fé. $\mathrm{O}$ fator pessoal e intransferível assume, por isso, um papel fundamental. Não se trata, porquanto, de algo que possa ser aprendido (apreendido) ou ensinado a partir de fora - por um código genético e/ou influência social - mas do protagonismo de quem constrói o seu próprio mundo de sentidos e significados - donde resulta a imposição de nomia, conforme já advertira Peter Berger (1985). Como bem delineou Mauro Amatuzzi (1998), em pesquisa empírica sobre a experiência religiosa, trata-se do movimento de abertura da pessoa a uma realidade inteiramente nova. A inauguração de uma nova percepção da realidade circundante, mas também da interioridade de cada indivíduo. Residiria nesse mergulho para dentro de si, traduzido como processo de "emancipação", a chave de leitura para o surgimento e a propagação das chamadas "espiritualidades" não religiosas - entre as quais poderíamos inscrever não os simplesmente "sem religião" (no sentido de indiferentes), mas os "crentes sem religião" (no sentido de "desinstitucionalizados" dos credos tradicionais)?

Nesse sentido, em que medida seria importante aqui o papel da chamada "matriz religiosa brasileira”, como tematizou Bittencourt Filho (2003)? Não é incomum que o distanciamento das instituições religiosas correspondentemente não impeça a manutenção de suas simbologias, como curiosamente notamos no relato da jovem dita "sem religião": "ao estudarmos a Bíblia compreendemos o plano de Deus e conhecemos a sua palavra. O conhecimento da Palavra de Deus nos ajuda a colocar em prática os princípios aprendidos, compartilhando com o próximo” (cf. LEMOS; SOUSA; MARTINS FILHO, 2018, p. 222). Estaríamos, 
então, realmente diante do fenômeno da descrença ou apenas do descrédito institucional?

Como dissemos, devemos admitir que o campo religioso brasileiro permanece dominado pela matriz cristã, uma vez que notamos que as ramificações católica e evangélica abarcam quase 90\% dos brasileiros afiliados a alguma religião em nosso país - segundo os dados do último censo. A essa ampla maioria somam-se ainda outras religiões e movimentos que têm alcançado penetração e expressividade cada vez maiores. Entretanto, mesmo dentro do contexto dessas manifestações cristãs majoritárias encontramos marcas de diversidade e pluralismo que correspondem a contingências históricas e a conjunturas sociais e culturais das mais diversas. Isso porque mesmo acerca do cristianismo brasileiro é sempre necessário termos em conta a noção de "matriz religiosa", que de modo algum permaneceu isenta às constantes bricolagens com tradições indígenas e africanas, por exemplo obrigando-nos a falar em termos de "cristianismos", no plural.

Desse modo, a aparente hegemonia do cristianismo não quer indicar o engessamento da experiência religiosa em uma ou outra religião - entendida em termos de institucionalidade - mas a maleabilidade inerente aos processos culturais que constantemente aproximam e distanciam, apropriam-se e recusam elementos das mais diferentes referências originárias. $\mathrm{Na}$ esteira desse argumento, a realidade observada aponta um momento propício para a busca do sagrado, independente da religião (ou falta desta) a ser adotada. Ainda que desprovida de vinculação institucional, parece manter-se o entendimento de que a crença sobrenatural contribui na qualidade de vida das pessoas, como fonte de sentido ou coesão.

Com origens remotas, o cenário religioso brasileiro continua a afirmar-se como um verdadeiro mosaico de experiências e vivências de "espiritualidades" que absorvem e moldam elementos próprios de umas e outras tradições. Como resultado, começamos a ver um sistema cultural que espelha o sincretismo e a extrema capacidade adaptativa dos indivíduos, capaz de absorver características externas e transformá-las em função de novos sentidos e significados. 
Em suma, o crescimento dos "sem religião" pode não equivaler ao fim da religião. Ao contrário, exige de nós a capacidade de nos aprofundarmos em sua compreensão, em busca de contribuições que, quiçá, servirão ao interesse das próprias instituições religiosas - não como exploração de marketing, mas de revisão de condutas, de reorientação dos passos, de adequação das linguagens, tal como ocorrera na passagem do século XIX para o XX. Fala-se cada vez mais no grande número de pessoas que deixaram de encontrar nas religiões tradicionais narrativas plausíveis a fim de responderem à suas demandas de sentido, passando a ter uma experiência do sagrado sem a mediação da instituição. De nossa parte, temos a impressão de que alguns fenômenos contribuíram para a composição deste status quo, o que tentaremos desenvolver em outra oportunidade.

\section{REFERÊNCIAS}

AGOSTINHO, S. Confisssões. Tradução de Maria Luiza Jardim Amarante. São Paulo: Paulus, 1984.

AMATUZZI, M. Experiência religiosa: busca de uma definição. Estudos de Psicologia, Campinas, v. 15, n. 1, p. 49-65, 1998.

ANTONIAZZI, A. As religiões no Brasil segundo o censo de 2000. Rever: revista de estudos da religião, São Paulo, n. 2, p. 75-80, 2003.

BERGER, P. L. O dossel sagrado: elementos para uma teoria sociológica da religião. São Paulo: Paulinas, 1985.

BITTENCOURT FILHO, J. Matriz religiosa brasileira: religiosidade e mudança social. Petrópolis: Vozes; Rio de Janeiro: Koinomia, 2003.

COSTA, C. L. F.; ECCO, C.; MARTINS FILHO, J. R. F. (org.). Epistemologias da religião e relações de religiosidade. Curitiba: Editora Prismas, 2017.

ECCO, C.; MARTINS FILHO, J. R. F. Culturas e ateísmos contemporâneos. Mosaico, Goiânia, 2017, v. 10, n. 2, p. 265-276, 2017.

GEERTZ, C. A interpretação das culturas. Rio de Janeiro: LTC, 1989.

GEERTZ, C. Nova luz sobre a antropologia. Rio de Janeiro: Zahar, 2001.

HEGEL, G. W. F. Werke in 20 Bänden. Frankfurt am Main: SuhrkampVerlag, 1970.

IBGE, Instituto Brasileiro de Geografia e Estatística. Manual do Recenseador: censo demográfico 2010. Rio de Janeiro: Ministério do Planejamento, Orçamento e Gestão, 2010. 
LEMOS, C. T.; SOUSA, I. F.; MARTINS FILHO, J. R. F. (org.). Juventude e religiosidade: o caso de jovens universitários. São Paulo: Fonte Editorial, 2018.

MARTINS FILHO, J. R. F. A controvérsia dos "sem religião" no Brasil: pluralismo religioso ou monoculturalismo cristão? Revista Eclesiástica Brasileira (REB), Petrópolis, v. 79, p. 663-681, 2019.

MARTINS FILHO, J. R. F. Um caminho nas Ciências da Religião: novas possibilidades para o catolicismo brasileiro. Caminhos, Goiânia, v. 18, p. 87-108, 2020.

MARTINS FILHO, J. R. F.; ECCO, C. Novos odres para o sagrado vinho: Marià Corbí e os sem religião. Estudos da Religião, São Paulo, v. 32, n. 2, p. 29-50, 2018.

MARTINS FILHO, J. R. F.; ECCO, C. Toward a Deep Spirituality: an Interview with Marià Corbí. Caminhos, Goiânia, 2017, v. 15, p. 149-161, 2017.

NIETZSCHE, F. Sämtliche Werke. Kritische Studienausgabe in 15 Bänden. Giorgio Colli und Mazzino Montinari (Hrsg.). Berlin: DTV \& Walter de Gruyter, 1980.

NOVAES, R. Os jovens "sem religião": ventos secularizantes, "espírito de época" e novos sincretismos. Notas preliminares. Estudos Avançados, São Paulo, v. 18, n. 52, p. 321-330, dez. 2004.

PIERUCCI, A. F. "Bye bye, Brasil” - O declínio das religiões tradicionais no censo 2000. Estudos Avançados, São Paulo, v. 18, n. 52, p. 17-28, dez. 2004.

TEIXEIRA, F.; MENEZES, R. Religiões em movimento: o censo de 2010. Petrópolis: Vozes, 2013. 